snowflakes under varying atmospheric conditions were then dealt with. Passing now to firnification, or the changes of the snowflake after lying on the ground, Mr. Seligman showed the complete cycle from newly-fallen snow to advanced firn snow by photomicrographs taken by him in the Alps and by scenic views illustrating the different kinds of snow surfaces encountered by the mountaineer or explorer. The process is essentially one of a consolidation of the fine, newly-fallen snow, occasionally containing as much as $89 / 90$ of air, to one of pure ice containing little or no air at all. The final stage of firnification, the genesis of glacier ice, has never been fully recorded, and this is to form the subject of a research now in course of preparation by the lecturer who showed tools for the purpose lying on the table. Dealing briefly with new snow avalanches, Mr. Seligman used some of his microphotographs of firnification to show why snow slopes do not as a rule become dangerous until the temperature has risen after a snowfall-a practical point of value to the ski-runner. Turning next to the effects of wind upon snow, Mr. Seligman showed photographs of a number of wind-formations, including sastrugi, comices, and snow 'wind-packed' or hardened by a wet wind. Wind-packed snow causes wind-slab avalanches, which consist of hard brittle drifts of snow lying loosely on steep slopes. These, if disturbed, break into blocks and form dangerous avalanches. A knowledge of the weather conditions which cause this type of avalanche has already proved of value to Everest climbers.

\section{Harry Price Library of Magical Literature}

To celebrate the transference of the library and records of the University of London Council for Psychical Investigation to the new University building in Bloomsbury, a dinner was held on January 22 at the Hotel Splendide. The occasion was also a mark of the Council's appreciation of the valuable work which Mr. Harry Price has done for psychical research and of his generosity to the University, and an illuminated testimonial to that effect was presented to him. The chairman, Dr. C. E. M. Joad, in complimenting Mr. Price, pointed out that in the early stages of all sciences, the experiments were carried out by private individuals at their own expense, and that it was to co-ordinate such activities and avoid acrimonious correspondence and personal animosities, that the Royal Society itself was founded. Mr. Price, in his reply, gave a short survey of the positive results of his many years of investigation, and concluded that sufficient evidence has been obtained to justify scientific investigation of telekinesis, thermal variations, teleplasmic masses, secondary trance personalities and extra-sensory perception of various kinds. The future of psychical research, he said, lies with the universities, and already there are six universities abroad taking the study seriously. The evening concluded with a demonstration by Mr. and Miss Tree, the foremost vaudeville telepathists in Britain. Their performance is remarkable for the extraordinary rapidity with which their code-system can be worked.

\section{The Society of Smeatonian Civil Engineers}

Among the least known engineering societies is that of the Smeatonian Society of Civil Engineers, which to-day exists mainly for social intercourse and has a small but select membership. When it was founded in 1771 it had as its aim the furtherance of professional knowledge. Its history has never been written fully, but on January 20, at a. meeting of the Newcomen Society held at the Institution of Civil Engineers, Mr. S. B. Donkin gave an interesting account of its early fortunes. From the technical point of view, the most lasting result of the Society was the publication in 1812 of the four volumes of the "Reports of the late John Smeaton". In the preface to this and in two minute books are contained what is known of the Society in its early days. It was the increasing demands being made on canal, harbour and bridge builders which led to the formation of the Society, it being felt that good results would accrue from members of the civil engineering profession meeting together to discuss their various projects. That they did so in a friendly manner can be seen from the minute of a meeting in 1778 which "was spent canallically, hydraulically, mathematically, philosophically, mechanically, naturally and socially". The original society founded in 1771 came to an end in May 1792 , but was almost immediately revived when, as the minute records, "The first meeting of this new institution The Society of Civil Engineers was held on the 15th of April 1793 by Mr. Jessop, Mr. Mylne, Mr. Rennie and Mr. Whitworth". Smeaton had been a leading figure of the old Society but he had died in October 1792. Soon after the revival of the Society, it learnt that Sir Joseph Banks had purchased all Smeaton's manuscripts and drawings, and it was with his concurrence the Society undertook the publication of Smeaton's "Reports". At the dinners, later on, five toasts were instituted, one of which was to "The memory of our late worthy brothers-Mr. Smeaton, Mr. Mylne, Mr. Watt and Mr. Rennie", and these toasts are still the order of the day at dinners of the Society. The Society, it may be added, had little, if anything at all, to do with the formation of the Institution of Civil Engineers, which arose from the efforts of half a dozen young engineers with their fortunes still to make.

\section{Recent Acquisitions at the Natural History Museum}

THE human remains from the Pleistocene deposits of Kenya Colony, on which much of Dr. L. S. B. Leakey's work is based, have been presented to the Department of Geology by the president and council of the Royal Society, through Dr. Leakey. The Mineral Department has received from the proprietors of the Hup Tuck Kongsi mine in the State of Selangor, Federated Malay States, the gift of an unusually large mass of cassiterite, showing numerous well-developed crystals. Cassiterite, which is more popularly known as tinstone, is almost the only source of tin and is therefore a valuable ore. Very occasionally it has been found in large enough crystals for eutting as gem-stones. The crystals in the present mass are at the best translucent at the surface. In colour they are mainly 